\title{
Disputas faccionais, batalhas jurídicas e construções midiáticas em uma eleição municipal
}

\begin{tabular}{c}
\hline \hline Igor Gastal Grill \\
Departamento de Sociologia e Antropologia \\
Universidade Federal do Maranhão \\
Eliana Tavares dos Reis \\
$\begin{array}{c}\text { Departamento de Sociologia e Antropologia } \\
\text { Universidade Federal do Maranhão }\end{array}$ \\
\hline \hline
\end{tabular}

\begin{abstract}
Resumo: 0 artigo apresenta resultados parciais de uma pesquisa mais ampla sobre as eleições municipais de 2008 no Maranhão. São enfocados os seguintes aspectos da dinâmica eleitoral: 1) a relevância assumida pelas chamadas "batalhas jurídicas" nas disputas eleitorais; 2) o trabalho de construção midiática dos "casos" envolvendo possíveis "cassações" de registro de candidaturas; 3) o papel dos advogados e de escritórios de advocacia especializados no "direito eleitoral" em equipes de campanha atuantes em distintos municípios do estado; 4) os usos feitos pelos membros das facções dos processos que transcorriam na justiça eleitoral. As fontes de informação utilizadas foram entrevistas realizadas com advogados, candidatos e coordenadores de campanha, além da análise da "cobertura" realizada pelos jornais O Estado do Maranhão e Jornal Pequeno durante a campanha eleitoral.
\end{abstract}

Palavras-chave: eleições municipais; mídia; batalhas jurídicas e facções; Maranhão

Abstract: This article presents partial results of an ample research on the municipal elections in the state of Maranhão in 2008. We focus on the following aspects of the electoral dynamic: 1) the relevance assumed by the so called "judicial battles" in the electoral disputes; 2) the media's constructive work on "cases" involving possible "cancellation" of candidate registration; 3) the role of lawyers and Law practices specializing in "electoral law" in campaign teams working in specific municipalities in the state; 4) the use made by the members of factions of the processes which were passing through the electoral law courts. The sources of information used were interviews done with lawyers, candidates and campaign managers as well as an analysis of the campaign "coverage" by the newspapers $O$ Estado do Maranhão and Jornal Pequeno during the electoral process.

Keywords: municipal elections; media; judicial battles and factions; state of Maranhão

OPINIÃO PÚBLICA, Campinas, vol. 18, n², novembro, 2012, p. $490-512$ 
GRILL, I. G.; REIS, E. T. Disputas faccionais, batalhas jurídicas e construções...

\section{Introdução}

A mobilização eleitoral é um momento privilegiado para análise do cruzamento e da atualização de lógicas que orientam e definem o jogo político. 0 estudo de processos eleitorais permite apreender o conjunto de mecanismos que agem na dinâmica política no qual ela é tributária da interdependência entre práticas e princípios múltiplos, forjados na intersecção entre diferentes domínios sociais. Com efeito, para além da explicitação das condições de concorrência entre si e da afirmação dos "homens políticos", em uma esfera específica, essas ocasiões trazem à tona estratégias e lutas que abrangem profissionais dos mais variados domínios (como os "operadores do direito" e os "produtores de imagens"). Assim, os estudos de eleições dizem não somente como esses vários agentes contribuem nos desdobramentos da disputa eleitoral, mas também podem iluminar as próprias bases de sua atuação profissional, redefinidas nessas inserções.

Este artigo expõe resultados parciais de uma pesquisa mais ampla sobre as eleições municipais de 2008 no estado do Maranhão (Brasil), a partir da qual foi evidenciada a relevância das chamadas "batalhas jurídicas" e do "palco midiático" no processo de concorrência eleitoral. Alguns eixos básicos orientaram o desenvolvimento desta reflexão.

Em primeiro lugar, leva em conta um viés da diversificação das carreiras profissionais no âmbito do Direito ainda pouco explorado na bibliografia: a especialização na esfera política. Em segundo lugar, busca compreender a atuação de determinados agentes dotados de competências específicas (muitas vezes associadas à ideia de expertise) em cenários marcados por clivagens do tipo faccionais (comumente considerados como típicas de ordens políticas "tradicionais", "atrasadas", "residuais", etc.). Em terceiro lugar, busca revelar alguns aspectos do entrecruzamento de transformações ocorridas nos espaços da política, do direito e da mídia, considerando as especificidades do caso brasileiro e, sobretudo, dos contextos, como os aqui analisados (eleições municipais em um estado do nordeste brasileiro). Por fim, pretende examinar uma face do imbricamento entre "política" e "direito", que parece negligenciada, qual seja, a dos usos do direito na luta política e sua transformação em trunfo eleitoral.

Um balanço da bibliografia sobre as distintas dimensões elencadas reforça a justificativa do enfoque ora assumido. A seguir, consideramos os referidos eixos e as ênfases que geralmente têm sido adotadas.

A forma clássica de relacionar profissionalização na política e usos do direito remonta ao trabalho pioneiro de Weber (1993), que grifou o destaque que os advogados adquiriram na esfera política em virtude da utilização de dois instrumentos que são recursos primordiais para o exercício da atividade política: a habilidade da escrita e o domínio da oratória. Na esteira das orientações weberianas, vários cientistas políticos abordaram os efeitos das osmoses, afinidades, proximidades e oportunidades tanto para a constituição de "viveiros" de carreiras políticas como para a constatação da presença de advogados na composição de instituições parlamentares (DOGAN, 1999; WILLEMEZ, 1999; GRÈZES-RUEFF, 1994; Santos e Serna, 2007; Perissinoto et al, 2009; GrILL, 2007; RodRIGUes, 2002; CoradinI, 1999; 2001). Em sentido inverso, negligenciou-se e negligencia-se o exame da atuação de advogados em empreendimentos políticos, sobretudo, em campanhas eleitorais, assessorias em mandatos 
OPINIÃO PÚBLICA, Campinas, vol. 18, n², novembro, 2012, p. $490-512$

parlamentares e para partidos, bem como o crescimento do papel de agentes formados em direito, nas últimas décadas, nesses meios.

Outra interface entre a "política" e o "direito" foi estabelecida a partir de investigações que têm se debruçado sobre o engajamento dos denominados "operadores do direito" (magistrados, promotores e advogados) em "causas políticas" ou "causas coletivas" (DeZALAY e GARTH, 2002; Roussel, 2001; GAITI e ISRael, 2003; ISRael, 2001; Willemez, 2003; Garraud, 2001 e 2003; EngelmanN, 2006; Garland, 2003) ${ }^{1}$. Essas pesquisas já constituem um campo consagrado de estudos delineado em torno de três elementos primordiais: as "estratégias dos movimentos sociais na apropriação do espaço judicial, o papel dos juristas na tradução e formalização das 'causas políticas' para a linguagem das disputas no interior do Judiciário e a conciliação da atuação profissional com o militantismo político" (ENGELMANN, 2006, p.125)2 ${ }^{2}$. Embora a mediação operada por certos profissionais do direito entre movimentos sociais e o Poder Judiciário tenha sido alvo recorrente de consideração, pouca atenção tem sido dada à ativação dos títulos escolares, saberes e competências profissionais ligados ao direito (somadas a outros recursos como administração de redes de relações pessoais, sociais e políticas) na constituição de equipes políticas. Soma-se a isso a centralidade da atuação desses agentes como assessores, consultores e conselheiros no trabalho multiforme de mobilização eleitoral (cada vez mais condicionado pela legislação eleitoral).

Por sua vez, os recursos de expertise, tal como consagrado na literatura internacional (DEZALAY e Garth, 2002; Matonti e Poupeau, 2006; Verrier, 2002 e 2006; Gaiti, 2002; Simeant, 2002, Dulong, 1996; entre muitos outros) e importado pelos pesquisadores brasileiros e latino-americanos (ENGELMANN, 2006; Santamaria e VeCChiolli, 2008; PetrarCA, 2009), têm sido exaustivamente identificados nos chamados "novos militantismos" (referentes às ONGS, "altermundismos", associações ecológicas, solidárias, "médicos sem fronteiras", "movimentos de direitos humanos", "redes de movimentos sociais", etc.). Esses são definidos em oposição aos "velhos militanstimos" ou "militantismo tradicional" (vinculado à adesão aos partidos e a sindicatos). Neste processo, observa-se a valorização de novos atores e recursos acionados nas militâncias (sobretudo a expertise), e a importância das redes formais e informais decorrentes da internacionalização de "causas". Mais do que assumir essa oposição, reivindicando a legitimidade de um estudo como o aqui empreendido (centrado em campanhas políticas municipais), cabe observar "a situação anterior e a atual e tudo o que é 'misto', híbrido, incerto, como os deslocamentos de um universo a outro, as reconversões ou as mobilizações” (CoLLOVALD, 2001, p.137).

Há, ainda, a oposição estabelecida entre a política central (institucional) e local (pessoal, faccional, etc.) ${ }^{3}$, a partir da qual criam-se obstáculos para se pensar a complexificação, a racionalização e a especialização das equipes políticas mediante o estudo de eleições municipais. O cenário propício para se identificar a codificação e regramento jurídico das disputas políticas seria, na perspectiva que

\footnotetext{
${ }^{1}$ A partir de outras abordagens teóricas, cabe citar também Bonelli (2002) e Viana et al (1997).

${ }^{2}$ Conforme o autor, sobre os advogados brasileiros, pode-se destacar a "mobilização de repertórios de "crítica da tradição jurídica' e 'novos usos' do direito", feitos no âmbito do direito de trabalho, da advocacia para sindicatos e da defesa de presos políticos na década de 1970, assim como são detectadas novas relações estabelecidas com os movimentos sociais a partir da década de 1990 (ENGELMANN, 2006, p. 124)
}

${ }^{3}$ Para uma crítica a essa oposição, ver Palmeira (2006). 
GRILL, I. G.; REIS, E. T. Disputas faccionais, batalhas jurídicas e construções...

prevalece, as instituições centrais (políticas e jurídicas), mediante as quais, em geral, deduzem-se os efeitos sobre a concorrência eletiva no conjunto do espaço nacional.

A análise da mobilização de competências profissionais na denominada "política tradicional" (no duplo sentido, referindo-se à política eleitoral e à política local) acaba não figurando na agenda estabelecida de estudos. Em vista disso, acredita-se na relevância da formulação de problemáticas que considerem tais dimensões, buscando, na ótica aqui seguida, perceber: Como se articulam as chamadas formas "tradicionais" de "fazer política" com o "fazer jurídico" dos profissionais ligados ao direito eleitoral? Como as modificações dos marcos legais de exercício da mobilização eleitoral se fazem presentes? Como se mesclam os distintos papéis prescritos para agentes atuantes no mundo jurídico em decorrência do pertencimento dos mesmos aos círculos locais das elites políticas e às regras morais e pragmáticas próprias às suas respectivas carreiras? Como os novos repertórios, linguagens e regramentos em constante redefinição, que os especialistas do Direito são capazes de decifrar, traduzir e instrumentalizar, se afirmam em consonância com as disputas faccionais, com as lutas entre "famílias", e são mobilizados por cadeias de líderes-seguidores?

Finalmente, cabem algumas considerações sobre a produção midiática e os usos dos "casos" jurídicos em situações históricas específicas. Os principais referenciais em voga, sobretudo na Sociologia Política francesa, tomam como chave explicativa as transformações ocorridas nos mundos jurídicos, midiáticos e políticos, que reconfiguram as teias de interdependência entre agentes situados em espaços distintos e, também, as relações possíveis entre diferentes subcampos sociais (MARQUETTI, 2000; 2001; Champagne, 1998; Neveu, 2006; Garraud, 2001; 2003; Musella, 2001). Ainda que os esquemas analíticos operados sejam altamente pertinentes para a apreensão dos fenômenos sociais de um modo geral, é preciso não se descolar do fato de que se está tratando de uma dinâmica singular e discrepante daquelas que motivaram a elaboração dos referidos modelos de análise.

Neste caso, é necessário frisar que a investigação se detém sobre uma configuração histórica marcada pela justaposição entre as múltiplas dimensões, lógicas e recursos de luta (inclusive sendo monopolizados por "famílias" e círculos restritos de uma elite com participação em distintas instâncias e fundados em redes de interconhecimento), sendo os diferentes protagonistas dos "casos" (políticos, jornalistas, advogados, juízes, etc.), assim como as instituições (partidárias, empresas de comunicação, escritórios de advocacia, instâncias jurídicas), partes integrantes de lutas entre facções ${ }^{4}$. Não é possível, então, simplesmente transpor os modelos de análise que constatam as transformações internas e externas simultâneas aos diferentes campos (jurídico, midiático e político); a existência de posições homólogas em cada um deles; a imposição de critérios de excelência ligados à capacidade crítica ou ao ideal de independência; e os usos feitos pelos diferentes protagonistas da legitimidade conquistada em um espaço político mais ampliado e diversificado.

\footnotetext{
${ }^{4}$ A utilização ao longo do texto da noção de facção é inspirada nas formulações de Landé (1977), Mayer (1977) e Boissevain (1977). São coalizões políticas rivais, instáveis e temporárias, centradas em lideranças personalísticas, cujos seguidores são recrutados de acordo com os recursos disponíveis para seus egos, que são capazes de gerar retribuições àqueles que aderem à sua liderança. Lagroye (2003) alerta que esse é um caso particular de configuração política, no qual prevalece o modelo reputacional e a mobilização sustentada por transações materiais e laços pessoais. Sawicki (2003), na mesma linha, salienta que é adequada a utilização quando há a prevalência da administração de uma hierarquia piramidal que atravessa vários níveis da política em detrimento de outros papéis constitutivos do métier político.
} 
OPINIÃO PÚBLICA, Campinas, vol. 18, n², novembro, 2012, p. $490-512$

\section{Agir por ricochete ${ }^{5}$ análise da cobertura dos jornais 0 Estado do Maranhão e Jornal Pequeno sobre a atuação do judiciário nas eleições de 2008}

Entre os maiores jornais do Maranhão, O Estado do Maranhão (EM) e o Jornal Pequeno (JP) configuram, atualmente, uma oposição e uma polarização que reproduz as clivagens mais gerais da política no estado ${ }^{6}$.

O primeiro é dirigido pelo empresário Fernando Sarney (irmão da atual governadora Roseana Sarney Murad e do atual deputado federal Sarney Filho), filho de José Sarney (ex-deputado federal, exgovernador, ex-senador pelo Maranhão, ex-presidente da República e atual senador pelo Amapá). Em 1968, o então governador do estado, José Sarney, passou a integrar o quadro societário do jornal e Bandeira Tribuzzi, poeta e seu principal assessor, passou a dirigir a redação do veículo. A primeira denominação do periódico foi O Dia - começou a circular em 1953 e, em 1959, foi adquirido pelo empresário e político Alberto Aboud. Somente em 1973, já sob o comando acionário do senador José Sarney, houve a modificação do nome para $O$ Estado do Maranhão. Atualmente, faz parte do Sistema Mirante de Comunicação, juntamente com rádios e televisão.

O Jornal Pequeno (JP), por sua vez, foi criado em 1951 por José de Ribamar Bogéa e segue como propriedade de sua família. Apesar de reivindicar na sua apresentação uma origem e uma continuidade constituídas a partir do seu caráter "independente" e "apartidário", desde a década de 1960, o órgão tem sido identificado com posicionamentos "antisarneysistas" no espectro de forças políticas. A rivalidade teria sido construída pelo fundador do veículo e persiste atualmente sob o comando do seu filho Lourival Bogéa.

A atualização dessas posições conflituosas no espaço de concorrência comercial e político pôde ser observada na campanha de 2008 , na qual foram lançados estigmas e expressões de desqualificação de parte a parte. Nas páginas do JP, como reação a suposta tentativa de enfraquecer os candidatos que se alinhavam ao pólo auto-denomidado "anti-sarneysista", o EM foi adjetivado de "central de mentiras", "piratas da moral alheia", "meios sarneysistas", etc. Enquanto no EM, o JP era referido como um "jornal governista", fazendo alusão à sustentação dada pelo veículo às gestões de José Reinaldo (PSB) e Jackson Lago (PDT) no governo do estado, além do próprio Jackson e Tadeu Palácio na prefeitura da capital7.

Apesar de não haver uma pesquisa específica sobre o tema, pode-se indicar que, no Maranhão, o acesso da população em geral aos meios impressos de comunicação é relativamente limitado. Conjugando-se a isso o fato de que a imprensa é altamente "politizada" e "partidarizada", reproduzindo as lógicas faccionais preponderantes, tem-se que certos veículos (como os jornais e os blogs) são espaços privilegiados de combate entre lados já definidos. Antes de serem lugares para "formar a

\footnotetext{
${ }^{5} \mathrm{~A}$ expressão foi utilizada por Marquetti (2001) para indicar a posição estratégica do espaço jornalístico nas lutas internas ao campo político e ao campo judiciário, assim como nas relações entre eles. Servindo, nos termos de Bourdieu (1989), ao mesmo tempo, aos fins esotéricos de cada universo e aos fins exotéricos de imposição de pontos de vista, de linguagens de legitimação e de imagens próprias em um espaço social mais amplo.

${ }^{6}$ Além desses, o Jornal 0 Imparcial também figura entre os maiores no estado.

${ }^{7}$ Muitos desses políticos estiveram unidos em 2006, no primeiro ou no segundo turno das eleições, a partir de uma coalizão que se autointitulou Frente de Libertação do Maranhão. Jackson Lago se elegeu governador apoiado por essas "forças" que reivindicavam o título de oposicionista ou de antisarneysistas. João Castelo foi candidato ao senado, sem sucesso. A gestão do pedetista foi dividida com quadros do PSDB, PSB, PT, PPS, PCdoB, entre outros partidos. Grande parte dos integrantes dessa "frente" apoiou João Castelo (PSDB) como candidato a prefeito em 2008.
} 
GRILL, I. G.; REIS, E. T. Disputas faccionais, batalhas jurídicas e construções...

opinião"8, eles servem para reforçar e instrumentalizar um posicionamento prévio, a favor ou contra uma determinada facção. Desta forma, ao contrário das dinâmicas em que ocorreram processos de produção de um lugar próprio para um tipo de jornalismo que concorre com o parlamento e a magistratura pelo exercício de vigilância dos usos e "abusos" do poder, há, nesse caso, uma configuração em que os meios midiáticos estão enredados na engrenagem de lutas políticas e são mesmo peças importantes de demonstração e mensuração de forças.

Por esses motivos, os periódicos ora examinados são fontes privilegiadas para a apreensão das lógicas de estabelecimento de elos e rivalidades que cortam o período eleitoral e sua articulação com discursos, valores e práticas que se impõem como universais. Assim, trazem à tona princípios subjacentes à dinâmica social rotineira e contribuem na composição ritualística das eleições como momentos que, nos termos de Turner (1974), sintetizam as representações que significam a vida social. Ou, mais especificamente, a análise desse material permite observar elementos que fazem das campanhas políticas esses “[...] momentos simultâneos de criação, repetição e concorrência entre símbolos políticos, expressando não só valores consensuais instituídos, como também conflitos típicos da sociedade contemporânea, incluindo múltiplos temas que cerceiam o mundo social" (BARREIRA, 2006, p. 179).

Analisando o conjunto de matérias publicadas entre julho e outubro de 2008 no JP e no EM, foram evidenciados os papéis híbridos desempenhados pela magistratura nas redes imbricadas e móveis que acionam o direito na luta política ou a tentativa de interferência da política nas decisões jurídicas, tendo em vista a mencionada inexistência de um princípio de relativa autonomia das esferas sociais.

Neste artigo, ressaltamos três grandes eixos que se definem por diferentes formas de articulação entre os mundos: "jurídico", "jornalístico" e a "política”. O primeiro é marcado por uma ideia da "justiça" como agente pedagógico e as matérias dos jornais simplesmente divulgaram as ações de juízes, promotores, advogados, etc. cumprindo seu "dever" de, por um lado, ensinar a prática política aos cidadãos e, por outro lado, controlar a prática política dos candidatos. No segundo, a ênfase aporta sobre as decisões judiciais e há uma ideia de "justiça" como agente de mediação e sanção, sobretudo no que diz respeito à viabilidade ou não de candidaturas no estado. Sobre isso, de um modo geral, os jornais manifestam brandamente algumas discordâncias e "preferências", um em relação ao outro, no que diz respeito às ações judiciais. E, por último, a centralidade incide sobre o julgamento da manutenção ou não de uma candidatura específica à prefeitura de São Luís. Nesse processo, a dramatização das tomadas de posição jornalísticas e jurídicas assume contornos peculiares, no qual há um cruzamento de denúncias, celebrações, desqualificações e apologias com diferentes focos e registros oriundos de diferentes domínios sociais.

\footnotetext{
${ }^{8}$ Há uma extensa bibliografia que aponta para o poder hierarquização e seleção de temas dignos de atenção; de enquadramento dos significados dos eventos; de formação de percepções induzidas pelos relatos; até de construção da realidade (NEVEU, 2006; ChAmpagne, 1998). Esses fatores não devem ser descartados. Contudo, os trabalhos que enfatizam esses aspectos analisam mídias mais diversificadas e que atingem contingentes mais amplos, contextos em que o impacto do jornalismo no conjunto da população é mais forte e, principalmente, em que se constitui um subcampo (o campo jornalístico) que rivaliza com o campo dos políticos pelo papel de representar a opinião pública. Para uma revisão da literatura e, inclusive, para a relativização da capacidade da mídia de construir a opinião do público no contexto francês, ver Gaxie (2003).
} 
OPINIÃO PÚBLICA, Campinas, vol. 18, n², novembro, 2012, p. $490-512$

\section{Os "Guardiões" dos Valores Democráticos}

O papel de agente pedagógico e moralizador da "justiça" é compatível com o caráter de guardião assumido por instâncias que zelam por um ideal de "democracia", comungado por todos aqueles envolvidos na transmissão de sentidos e práticas valorizadas (e valorizantes) que devem orientar as ações de cidadãos e homens públicos. Esse tipo de questão ampara-se na crença acerca da possibilidade de existência de cidadãos universalmente competentes para posicionar-se sobre a "política", pela qual, supostamente, nutririam um interesse universalmente compartilhado. Somam-se a isso circunstâncias em que o descrédito em relação ao jogo político e à conduta dos políticos garantem aos magistrados, mais do que nunca, assumirem o papel de salvaguardar o Estado de Direito e, com ele, os cidadãos.

No credo democrático, as "eleições sob o sufrágio universal, o princípio da maioria, a responsabilidade política dos governantes, etc." conferem "sentido às suas instituições fundamentais" (BRAUD, 1991, p.217). Assim, como foi dito anteriormente, na comunhão constitutiva de lógicas políticas e lógicas jurídicas sob uma ideia de democracia como sistema de governo fundado em crenças, as eleições ocupam um lugar de destaque no universo de ritos e práticas cerimoniais que "assemelham todos os cidadãos no ato ficcional: a formação da vontade geral que transforma uma comunidade imaginada em 'realidade'” (BRAUD, 1991, p.217).

Um conjunto de reportagens em ambos os jornais revela a inelutabilidade de tais princípios que formam a doxa democrática: por um lado, cobrando do "cidadão" um papel "fiscalizador" e "consciente"; por outro lado, antecipando e enquadrando possíveis infrações dos candidatos. Por esse intermédio, o processo eleitoral é exaltado, acima de tudo, naquilo que compete à ação preceptora, moralizadora e reguladora da "Justiça Eleitoral".

No primeiro ponto, por exemplo, o "cidadão" é chamado a "acompanhar pela internet demonstrativos dos gastos de campanha de cada candidato", a aderir aos projetos do TRE do tipo "fique de olho... fiscalize"; a "reagir" às "ações de conscientização do TSE"; a "denunciar crimes eleitorais"; a "conscientizar-se" da "necessidade do pleito eleitoral livre dos vícios e corrupção", entre outros.

Cabe grifar a eventual presença de "especialistas" autorizados a reproduzir e respaldar o jargão em pauta. Esse é o caso de um professor de filosofia da UFMA, que "alerta para promessas" dos candidatos, sublinhando que "essa atitude é natural, o problema é saber quando as propostas são viáveis ou uma falácia". Neste caso, segue a matéria: "o educador afirmou que os eleitores precisam ficar atentos para não serem enganados e sugeriu que eles procurem conhecer as atribuições de prefeito e de vereadores", pois, "às vezes nem o próprio candidato sabe o que de fato ele pode ou não pode fazer num mandato, caso ele seja eleito" (EM, 14/09/2008, p. 3). Na mesma reportagem, há o depoimento de um eleitor, sociólogo e padre, que elogia a "nova realidade" de "ação mais intensa de órgãos públicos, instituições e entidades de proteção ao cidadão", mas ressalta a insatisfatória "estrutura" do Estado, especialmente do Ministério Público, no sentido de "coibir uma prática que ainda resiste: a compra e venda de votos" (EM, 14/09/2008, p. 3). Adicionam-se a esses, além da constante manifestação de juízes e promotores eleitorais, entrevistas com "especialistas em legislação eleitoral", como aquela dada ao JP, em 7 de setembro, na qual o advogado consagra a eleição municipal como "a mais importante", 
GRILL, I. G.; REIS, E. T. Disputas faccionais, batalhas jurídicas e construções...

pois, "é ela que conquista verdadeiramente o cidadão, que desperta paixões acirradas" e na qual a população "é verdadeiramente partícipe do processo político" (p.15).

De qualquer modo, quando o acento recai sobre a celebração dos desdobramentos da dinâmica eleitoral, o "saldo é positivo" - o que se coadunaria à eficácia (e eficiência) da ação da Justiça Eleitoral. Especialmente sobre isso, as temáticas mais recorrentes são a "lisura do pleito eleitoral" pregada pelos magistrados e o TSE, a melhor "estruturação das eleições", a "fiscalização mais rigorosa", no que tange aos gastos de campanha, propaganda, prestação de contas de poder político e econômico, vantagens da minirreforma eleitoral da Lei n¹1.300/2006 como o "barateamento dos custos das campanhas", maior "transparência aos olhos da população", realização de audiências públicas com juízes sobre "eleições limpas", etc.

No tocante ao segundo ponto, sua fertilidade reside no fato de que os políticos aparecem como um dos, senão os únicos, possíveis contaminadores de uma "eleição limpa" e, portanto, é sobre suas condutas e procedimentos que a "justiça” deve agir, sancionar, normalizar e morigerar. Com esse intuito, é publicada uma gama de "alertas", proibições e disciplinamentos: "prestação de contas de candidatos", "abusos", "crimes", “infrações na propaganda eleitoral", "candidaturas de políticos com "ficha suja'”, "utilização de recursos ilícitos", "termos de ajuste de condutas", "compra de votos", "pinturas irregulares em muros e veículos", "poluição visual e sonora", "condutas vedadas aos agentes públicos em campanha", "excessos na propaganda eleitoral", constar ou não na "lista negra" da Associação dos Magistrados do Brasil, etc.

Ao contrário do noticiário anterior, com teor e interpretação mais "consensuais" e de caráter informativo nos dois jornais, essas últimas abrem brechas para a manifestação de rejeições de candidaturas mediante o recurso de ilustração das notícias. Quer dizer, não raro, a divulgação de casos de "pinturas irregulares em muros e veículos" e de "poluição visual e sonora" são oportunidades de estampar a foto de um candidato "do outro lado".

Para ilustrar, a manchete publicada no EM de 18 de agosto destaca "Operação combate os excessos na propaganda eleitoral em SL. Carros de som são apreendidos por causarem poluição sonora na capital", com a foto do carro de som do candidato João Castelo (PSDB) com a seguinte legenda: "carro de som de campanha eleitoral apreendido ontem é escoltado por viatura da Polícia Federal" (p.2). E, no dia 29 de agosto, o JP aponta sobre "poluição sonora": "Blitz apreende 27 carros de som de campanha eleitoral" e traz na imagem o carro de som do candidato a prefeito da capital Raimundo Cutrim (DEM), ex-secretário de segurança de Roseana Sarney. Todavia, nem sempre a ação judicial é frisada por sua credibilidade. Eventualmente, aparecem notas jornalísticas que questionam sua veemência e imparcialidade frente aos "candidatos poderosos". Esse é o caso daquela publicada no JP de 27 de setembro referente às "críticas à Justiça de dois pesos e duas medidas adotadas contra os que não têm costas quentes, e de vista curta em favor daqueles que são protegidos por figurões, como juízes e políticos mais influentes" (p.5). A nota contesta o não cumprimento da notificação proibindo a colagem de cartazes em postes e muros em determinados locais da capital, por parte de "apadrinhados de medalhões" e conclui interrogando: "queremos ver, agora, qual o juiz de zona eleitoral será capaz de mandar retirar os cartazes" (p.5). 
OPINIÃO PÚBLICA, Campinas, vol. 18, n², novembro, 2012, p. 490 - 512

Um segundo conjunto de notícias publicadas foi centrado nos processos de impugnações e cassações de candidaturas. Nos dois periódicos, essas matérias foram mais intensas durante os meses de julho e setembro. Nelas foi acentuado o montante de candidaturas frustradas pelo Ministério Público nos municípios maranhenses, que, na maioria dos casos, teve como motivo a rejeição de contas de gestão, pelo TCE e TCU, de prefeitos, vice-prefeitos e vereadores (ex-gestores públicos). Outras razões para indeferimentos foram as acusações de "compra de votos" e uso da "estrutura do estado" nas campanhas.

Sobre a primeira, um caso exemplar foi a denúncia de distribuição de dinheiro e bens materiais de um candidato à prefeitura em um município no interior, feita pelo EM, em 6 de setembro. Com a candidatura confirmada e tendo sido reeleito o candidato, em outubro, o mesmo jornal publicou duas reportagens apontando a "estreita ligação" entre o promotor atuante no processo de pedido de cassação e o então prefeito filiado ao PDT, ilustrando o vínculo com uma foto dos dois abraçados. Além disso, um tratador de cavalos do promotor atestou em depoimento ser pago pela administração municipal, que também teria "bancado" a construção da baia onde os cavalos eram cuidados. E, ainda, que a Chácara do promotor, em um povoado localizado em um dos municípios constituintes da Ilha de São Luís (Paço do Lumiar), fora cercada com "dormentes" apreendidos por ele próprio "por terem sido fabricados com madeira não autorizada pelo IBAMA" (EM, 21/10/2008, p.2).

A ação propondo a suspeição do promotor na ação contra o prefeito foi movida por coligação que teve como candidata a ex-deputada Teresa Murad (PMDB) e teve como testemunha, assinando a representação contra o representante do MP, seu marido e então líder da Oposição na Assembleia Legislativa, o deputado Ricardo Murad (PMDB), cunhado de Roseana Sarney ${ }^{9}$. Na mesma matéria do EM, o deputado Ricardo Murad ressaltou que essa era a primeira vez que se conseguia "comprovar que um promotor está, de forma indireta, na folha de pagamento de um prefeito reeleito na fraude" e sentenciou: "ou a Justiça Eleitoral dá um basta no abuso do poder econômico nas eleições no Maranhão ou não teremos mais eleição" (EM, 19/10/2008, p. 2).

Se a decisão de deferimento gerou a indicação de envolvimentos de um "agente da justiça" nos jogos faccionais locais, expostas no EM, cabe aludir à suspeição da opção de indeferimento, suscitada no JP, na qual o juiz eleitoral teria agido "contra a orientação do Tribunal Superior Eleitoral". Duas matérias foram publicadas no mesmo dia (23 de agosto) no JP questionando a negação do registro da candidatura à reeleição de um prefeito pedetista do interior de estado, classificando a determinação como mais um dos "absurdos do Maranhão" e interrogando: "o que levaria um juiz de Direito a indeferir um registro de candidatura contrariando uma decisão do Tribunal Superior Eleitoral, a instância maior da Justiça eleitoral do país?" (JP, 23/08/2008, p. 2 e 3) $)^{10}$.

\footnotetext{
9 Para mais detalhes da sua trajetória, ver Grill (2008).

10 A deliberação do juiz estaria baseada na rejeição das contas do prefeito pelo TCU em 2005. Contudo, haveria uma ação anulatória conseguindo uma "Iiminar de antecipação de tutela no Tribunal Regional Federal da 1a. Região, em Brasília, afastando, dessa maneira, os efeitos da decisão do TCU até o julgamento final da ação pela Justiça Federal de $1^{\text {a }}$. instância" (JP, $23 / 08 / 2008$, p. 3). A contestação, então, se fundamentava no fato de que, desde 2006 , o TSE estabeleceu que os candidatos com contas rejeitadas poderiam entrar na Justiça e "conseguir uma decisão liminar em antecipação de tutela ou cautelar afastando assim a inelegibilidade do art. $1 .^{\circ}$, I, alínea "g", da Lei Complementar n 64/90 e os demais efeitos da decisão do órgão competente, que, no caso, é o TCU" (idem).
} 
GRILL, I. G.; REIS, E. T. Disputas faccionais, batalhas jurídicas e construções...

Observou-se, pois, a distinção entre diferentes níveis e apropriações de uma ideia de "justiça". Tais fatores se traduzem igualmente nas formas distintas de emergência do discurso jurídico no espaço jornalístico à luz das "questões eleitorais". Há a adesão a princípios de uma moral cívica vigente e o reconhecimento do papel do judiciário no zelo desses valores que são ativados nas matérias jornalísticas, constituindo alianças entre os personagens desses domínios em contraste com a "classe política". Igualmente, observa-se um nivelamento dos atores que operam no âmbito da justiça em relação aos políticos e aos mecanismos das disputas faccionais e com os códigos de reciprocidade e de hostilidade próprios das clivagens políticas nesse cenário. Nesse caso, as aproximações com agentes do judiciário e com políticos produzidas são seletivas e acionadas de acordo com o posicionamento político do veículo, associando uma posição de crítica à ligação entre juízes ou promotores e candidatos (logo, de externalidade e superioridade) e uma identificação faccional (logo, de envolvimento explícito e de utilização como instrumento de luta política).

\section{"Batalhas" jurídicas, políticas e midiáticas em torno do "caso Castelo"}

O início do mês de julho foi marcado pelo anúncio das possíveis impugnações das candidaturas de Flávio Dino (PCdoB) e de João Castelo (PSDB). Esses dois candidatos, de certo modo, polarizaram as expectativas e especulações de vitória na eleição municipal da capital do Maranhão em 2008.

Disputando pela primeira vez uma eleição majoritária, o deputado federal Flávio Dino (PCdoB), eleito em 2006, é advogado e ex-juiz federal. Filho de um ex-deputado estadual, que ocupou vários cargos de primeiro escalão em governos estaduais, Dino era o mais jovem entre os principais concorrentes no pleito de 2008 e se apresentava como sinônimo de renovação da política maranhense. Chegou ao segundo turno exibindo um trajeto profissional repleto de títulos (como a aprovação em primeiro lugar no concurso nacional para juiz federal e para professor da UFMA), um percurso de "militâncias" (líder estudantil, advogado de sindicatos, vice-presidente da Associação dos Juízes Federais, presidente do Conselho da Justiça Federal e Secretário da Comissão de Altos Estudos da Justiça Federal) ${ }^{11}$, além dos apoios de ministros do PT e PCdoB, dos chamados membros de organizações da sociedade civil e de algumas das lideranças estaduais do PT.

João Castelo, concorrendo pela quarta vez como candidato a prefeito de São Luís, utilizou como principal trunfo de campanha, sintetizado na ideia de "experiência", o currículo de cargos públicos ocupados (sobretudo administrativos) e a apresentação das realizações da sua gestão no governo do estado entre 1979 e 1982. Filho de desembargador, ele atua como empresário e é formado em direito pelo Centro Universitário de Brasília (Distrito Federal). Ocupou vários cargos administrativos entre 1954 e 1970. Elegeu-se deputado federal, pela Aliança Renovadora Nacional (ARENA), em 1970 e 1974. Em 1978, foi escolhido como candidato da Arena para concorrer a governador, tendo sido eleito pela Assembleia Legislativa. Concorreu, com sucesso, ao Senado em 1982 e indicou seu primo, João Rodolfo Ribeiro Gonçalves, para concorrer a vice-governador nas mesmas eleições. Em 1985, investiu no lançamento da sua esposa, Gardênia Gonçalves, como candidata à prefeita de São Luís, obtendo êxito e derrotando o candidato (Jaime Santana) apoiado pelo então presidente da República, José Sarney. Em

11 Sobre esse itinerário, ver Barros Filho (2008) e Tavares dos Reis e Grill (2008b). 
OPINIÃO PÚBLICA, Campinas, vol. 18, n², novembro, 2012, p. $490-512$

1986 e 1990, concorreu a governador, sem sucesso, perdendo as eleições para Epitácio Cafeteira e Edison Lobão (candidatos da "família Sarney" e aliados). Sofreu derrotas também nas eleições para o Senado, em 1990, 1994 e 2006 (nesta última com o apoio do então governador José Reinaldo Tavares, dissidente da sua facção de origem, e do governador eleito nestas eleições, Jackson Lago), e para a prefeitura de São Luís em 1996, 2000 e 2004. Nas últimas décadas, se elegeu, ainda, deputado federal duas vezes, pelo PSDB, em 1998 e 2002. No governo de Jackson Lago, foi presidente da Empresa Maranhense de Administração Portuária (EMAP). Sua filha é deputada estadual pelo PSDB. Esses e outros políticos que participaram da chamada "Frente de Libertação do Maranhão"12, em 2006, apoiaram João Castelo, em 2008.

Contra Dino, candidato da coligação "Unidade Popular" (PT/PCdoB), as principais acusações foram feitas pelo PTN e pelo PSOL, respectivamente, por: 1) "prática de gastos ilícitos", mais especificamente, ele teria "infringido a legislação ao realizar eventos de campanha antes de ter uma conta bancária dedicada a isso" (JP, 15/7/2008, p.3); 2) e por publicar um artigo no JP (no qual tinha uma coluna semanal), o que seria vedado aos candidatos (EM, 17/7/2008, p.3). Ao contrário de Castelo, no entanto, ele conseguiu provar que estava "quite" com a Justiça Eleitoral.

As principais representações contra João Castelo, da coligação "São Luís merece mais" (PSDB, PSB e PTC), no TRE, foram encaminhadas pela já mencionada coligação "São Luís não pode parar", liderada pelo então candidato à prefeitura da capital Clodomir Paz (PDT), e pela coligação "A força das comunidades" (DEM, PRTB e PTdoB), encabeçada pelo então deputado estadual e igualmente candidato à prefeitura, Raimundo Cutrim (DEM). O motivo das tentativas de impugnação foi o não pagamento de duas multas eleitorais, no valor de $\mathrm{R} \$ 21.000,00$ cada, nas eleições de 2006 , quando Castelo concorreu ao Senado.

Sublinham-se, nesse processo, os editoriais como espaços singulares de manifestação do posicionamento dos periódicos (EM e JP), como "lugares de opinião" explícitos, distintamente daquele ocupado pelas reportagens jornalísticas assinadas, em que parece haver uma maior cautela nas tomadas de posição assumidas. Isso não significa dizer que os agentes (jornalistas), especialmente dedicados às "matérias políticas", não revelem - desde os títulos das notícias até os trechos de depoimentos selecionados, dados ressaltados, enfim, as ênfases conferidas nos seus comentários - os filtros necessários à sustentação dos posicionamentos defendidos nos seus veículos de trabalho. Porém, pode. se observar, relativamente aos editoriais, que esses "pontos de vista" são mais codificados em uma linguagem relativamente técnica, o que pretensamente permitiria sua "credibilidade jornalística".

Curioso atentar para o fato de que os editoriais dos dois jornais no dia 16 de julho destacaram o momento de "guerra judicial" (EM) e "batalha judicial" (JP) do processo eleitoral, sendo que o primeiro para grifar a condição de suspeição por inadimplência de Castelo e o segundo enfatizando a possível instrumentalização da "Justiça" como "arma para barrar os adversários".

No primeiro momento, o EM explorou "o caso Castelo" de variadas formas, sobretudo com reportagens e notas que apresentavam e destacavam o candidato e a candidatura como vulneráveis: "sob

\footnotetext{
${ }^{12}$ Movimento organizado em torno das lideranças do ex-governador José Reinaldo Tavares e do governador eleito, em 2006, Jackson Lago, que reunia adversários da facção centralizada pela "família Sarney".
} 
GRILL, I. G.; REIS, E. T. Disputas faccionais, batalhas jurídicas e construções...

risco", "ficha suja”, em "situação grave”, "sob judice”, “desorganizada”, "encrencado", "inadimplente”, "dúvida" de sua elegibilidade, "ilegalidade" da candidatura, etc. Ao passo que o JP, nessa fase de indefinição sobre o registro do tucano, optou por somente divulgar as avaliações e posicionamentos de defesa do advogado José Antonio Almeida, confirmando que Castelo estaria "quite" com a Justiça Eleitoral.

Já de início, o EM repercutiu a ideia de que o advogado de Castelo, definido como "um dos bambas locais do Direito Eleitoral" (ver próxima seção), culpava o TRE pela impugnação, porque não teria notificado seu cliente sobre as referidas multas. Isto é, José Antônio Almeida, estaria utilizando como principal estratégia de defesa a responsabilização da Justiça Eleitoral pela "encrenca" em que estava "metido o tucano".

Sobre o processo de notificação, Almeida empenhou-se em esclarecer sua interpretação de que haveria uma fase "jurisdicional" e uma "administrativa":

"A primeira fase se findou com o trânsito em julgado no TSE, que ocorreu em março deste ano. A outra, a administrativa, é justamente a citação do candidato para pagar a multa, voluntariamente, antes que seja encaminhada para execução fiscal na Secretaria da Fazenda Nacional. E foi a citação que não ocorreu" (EM, 17/7/2008, p.3).

Tais declarações teriam causado um "mal-estar" naquele Tribunal. No dia seguinte à reportagem anterior (intitulada: "Advogado de Castelo culpa TRE pela impugnação do candidato"), a matéria em destaque foi: "TRE nega ter responsabilidade pela impugnação de João Castelo". Nessa última, as explicações são do diretor-geral do TRE sobre não haver necessidade de o Tribunal "notificar os candidatos sobre o pagamento dos seus débitos"; que o candidato "tinha pleno conhecimento da sua dívida, tanto que usou todos os recursos para contestá-la, até no TSE"; que a certidão de quitação eleitoral fornecida a Castelo não seria comprovante de inexistência de débito, pois essas "atestam apenas se o cidadão está ou não em dia com suas obrigações como eleitor, se votou nos últimos pleitos, por exemplo. Não se referem a dívidas com a Justiça Eleitoral" (EM, 18/7/2008, p. 3).

$\mathrm{O}$ argumento de que Castelo não foi devidamente notificado de sua citação no processo de cobrança de multa eleitoral foi questionado por Marcos Coutinho Lobo'13 (advogado da coligação "A força das comunidades"): "como ele não foi notificado se há até recurso de sua autoria contra a decisão da Justiça Eleitoral?", frisando que "ele tem o direito de estrebuchar, mas o fato é que não existe essa história de a Justiça notificar sobre decisão transitada em julgado" (EM, 17/7/2008, p. 3).

Desta forma, observa-se a confluência de reportagens no EM que sustentam, sob várias bases, que a decisão pela cassação do registro da candidatura seria a única coerente a ser adotada pela Justiça Eleitoral. Dentre elas, o esforço em detectar que a "Jurisprudência da Justiça Eleitoral dificulta a defesa de João Castelo", pois o "argumento da falta de citação sobre multa" já teria sido "derrubado por outros TREs" (EM, 19/7/2008, p. 3).

\footnotetext{
13 Advogado que dirige um dos mais importantes escritórios especializados em direito eleitoral do Maranhão. Foi advogado da coligação "Maranhão - A Força do Povo" no processo de cassação de Jackson Lago que permitiu o retorno de Roseana Sarney ao governo do estado. É o atual Procurador Geral do Estado licenciado.
} 
OPINIÃO PÚBLICA, Campinas, vol. 18, n², novembro, 2012, p. 490 - 512

De um modo geral, as notícias divulgadas durante o mês de julho no EM foram direcionadas, por um lado, no sentido de desacreditar as estratégias e procedimentos de Castelo e da sua defesa. Por outro lado, no sentido de tornar vulnerável a candidatura como uma opção eleitoral viável e factível.

No dia 8 de agosto de 2008, são apresentadas reportagens nos dois jornais, JP e EM, com a deliberação do MPE acerca da candidatura de João Castelo, com os seguintes e respectivos títulos: "Parecer do Ministério Público garante candidatura de Castelo" (JP, 8/8/2008, p. 3, grifo nosso) e "Promotores opinam que Castelo poderá ser candidato" (EM, 8/8/2008, p. 3, grifo nosso).

A partir da primeira decisão favorável a João Castelo, o JP passou a divulgar mais sistematicamente matérias sobre o "caso", sobretudo, por um lado, atacando as investidas do EM e o que representariam em termos de dominação "sarneisista" e, por outro lado, vinculando a candidatura de Castelo à "vontade do povo" e à "soberania popular". Logo, a sua cassação significaria um "golpe" contra o "povo", a "vontade popular" e o Estado democrático. Ideia essa sustentada na ocupação por Castelo do topo das "preferências" de voto apontadas nas pesquisas eleitorais ${ }^{14}$.

Diretamente redigido contra o EM, o editorial do dia seguinte ao parecer do MPE buscava interpretar "as filigranas de uma matéria jornalística, aquilo que pode ser lido nas entrelinhas ou se esconde nos bastidores de uma redação mal intencionada, [que] não podem ser percebidas por todo mundo. [...] nítida intenção de indispor o candidato, o Ministério Público e, quem sabe, até o juiz da primeira zona eleitoral do TRE [...]" (JP, 9/8/2008, p. 2). E segue desqualificando o periódico e atribuindo a ele adoção de práticas que, no estado, são comumente acionadas pelos antagonistas para caracterizar o que chamam de "oligarquia" (todos aqueles de alguma forma ligados à "família Sarney").

O EM, na mesma data, desfere contra a comemoração antecipada do JP, adjetivado de "jornal governista", que teria surpreendido "ao fazer festa" e afirmar "em tom de sentença" que "Parecer garante candidatura de Castelo". Advertindo: "O problema é que o mancheteiro esqueceu que parecer de MP não é sentença!!" (EM, 9/8/2008, p. 3).

A mesma edição traz reportagem centrada na figura de Daniel Leite que diz respeito a uma passagem do parecer ministerial sobre as impugnações contra Castelo em que há "insinuações de que ele teria cometido "patrocínio infiel'" (Idem). Quase um mês antes disso, em notícia que imputava a Castelo o descaso pela impugnação, havia uma referência a "insinuações feitas por José Antônio Almeida de que o processo na justiça teria sido decorrente da ação "eticamente responsável" do advogado anterior de Castelo, que não teria o comunicado da decisão do TSE sobre a multa (EM, 18/7/2008, p.3). Alegando que não tivera contrato de trabalho com o referido candidato, e que somente "prestou o favor de entrar com um 'Agravo de Instrumento, que nem foi conhecido pela Justiça Eleitoral porque intempestivo'”, Leite defendeu-se: “Repilo com veemência a insinuação do Ministério Público de que tenha havido ocultação de informações para prejudicar Castelo. É uma sugestão completamente descabida [...]. Eu também poderia levantar questionamentos sobre o parecer. Afinal, tem uma relação quase espiritual com a defesa do candidato [...]" (EM, 09/08/2008, p. 3).

\footnotetext{
14 Observa-se como as pesquisas de estimativa de intenção de votos podem ser acionadas no jogo político como um atestado de aferição da opinião pública que, em certa medida, torna prescindível o próprio ato do voto. A sondagem passa, com efeito, a ser considerada um procedimento democrático e expressão da vontade popular a ser respeitada (CHAMPAGNE, 1998).
} 
GRILL, I. G.; REIS, E. T. Disputas faccionais, batalhas jurídicas e construções...

A repercussão da existência de tal envolvimento apenas foi explorada com maior intensidade após a divulgação da sentença do juiz da $1^{\text {a }}$ Zona Eleitoral, no qual a "Justiça Eleitoral confirma a candidatura de Castelo" (JP, 12/08/2008, p.3) e o "Juiz defere a candidatura de João Castelo à Prefeitura de São Luís" (EM, 12/08/2008, p.3). A partir dessa decisão e até o final do mês de agosto, as matérias publicadas no EM parecem tatear na redefinição de novas alternativas "eleitorais" de disputa.

Neste caso, o EM, por um lado, parte da constatação do desempenho do candidato do PSDB nas pesquisas para suscitar indicações sobre as estratégias dos demais candidatos com vistas a levar a eleição para o segundo turno: "a campanha vai pegar fogo", "ele certamente será alvo preferencial de boa parte dos candidatos", "a briga pra valer começa agora", "denúncias contra adversários talvez sejam a melhor forma de tentar despertar a atenção do eleitor", etc. E, por outro lado, persistem assinalando a sequência da "guerra": "coligações recorrerão ao TRE contra candidatura de Castelo", "Tribunal indefere registros de concorrentes por dívidas com a justiça eleitoral", "TRE recebe novos argumentos sobre a candidatura de Castelo", "Defesa do tucano admite que notificação de multa eleitoral não é obrigatória", "Advogados contestam a decisão do juiz da $1^{\text {a }}$ Zona Eleitoral favorável ao tucano".

Diante dos novos recursos contra a decisão favorável a Castelo, os dias que antecederam à decisão do processo, no final do mês de agosto, foram marcados também pela contundência das defesas do candidato e as denúncias dos possíveis "golpes" forjados contra ele, publicadas no JP. Assim, a base dos argumentos acionados nos posicionamentos expressos nesse periódico possui uma feição muito mais moral e emocional. Pressupondo a legalidade da candidatura, mas, sobretudo, sobrepondo o valor da "vontade do povo", supostamente manifesta nas pesquisas, à própria condução e avaliação judicial (definindo nesses termos uma concepção específica de "Justiça"), a possibilidade de sua cassação aparece como fruto de ações "espúrias", "desonestas", "antiéticas", "antidemocráticas" etc. em andamento ou passíveis de serem adotadas. Destaca-se a passagem: "Deputado diz que tentativa de tirar Castelo da eleição é uma vergonha. [...] é a tentativa desesperada dos candidatos adversários de João Castelo de excluí-lo da disputa eleitoral, para tentar ganhar fácil [...]"(JP, 21/8/2008, p. 3).

Outras declarações do deputado tucano citado no fragmento tiveram algum destaque no mesmo jornal, após o parecer do Procurador Eleitoral contra o registro da candidatura de Castelo. Enquanto o EM, em editorial, recupera que esse resultado "confirma alerta da coluna aos jornais governistas, que fizeram festa antes da hora" (28/08/2008, p.3), a descrição da notícia no JP ocupa metade da matéria, e na outra metade retoma os argumentos utilizados pelo juiz da $1^{\text {a }}$ Zona Eleitoral, para sustentar sua decisão favorável ao candidato. Na mesma página, em texto destacado em box, há a chamada: "Deputado condena atitude de advogado de Castelo". Tratava-se da denúncia feita pelo parlamentar no seu pronunciamento em sessão da Assembleia Legislativa do dia anterior, no qual afirmou que Castelo teria sido "vítima" de uma "jogada suja" operada por seu ex-advogado, Daniel Leite $^{15}$, pois teria "escondido a notificação" (JP, 28/08/2008, p.3).

\footnotetext{
${ }^{15}$ Proprietário de importante escritório de advocacia em São Luís, que reivindica em seu site ter se "destacado na consultoria contenciosa em diversas áreas do conhecimento jurídico, notadamente no Direito Eleitoral, Administrativo, Tributário, Societário, Contratual e no campo da Responsabilidade Civil". Disponível em: <http://www.advocaciaassociada.com.br/danielleite>. Acesso em 03 jul. 2010). Seu pai foi membro de primeiro escalão de gestões do PDT na prefeitura de São Luís. Já assessorou diversas campanhas de importantes políticos maranhenses, atuou como advogado de Jackson Lago na campanha de 2006 e no processo de sua cassação, bem como defendeu vários prefeitos do interior.
} 
OPINIÃO PÚBLICA, Campinas, vol. 18, n², novembro, 2012, p. $490-512$

A resposta do advogado, que afirmou que processaria civil e penalmente o deputado, foi publicada no EM. Neste veículo, ele nega qualquer "jogada suja" ou "atitude anti-ética" (EM, 31/08/2008).

O embate entre deputado e advogado foi noticiado nos dois jornais, mas obteve menor destaque no EM (salientando o "clima" de "beligerância verbal", que "bateram boca em emissora de rádio", etc.) e maior no JP, como na manchete "Trama desmascarada na Assembleia Legislativa. Deputado denuncia tentativa de golpe para tirar castelo do páreo', na qual são apresentadas as "provas" do que seria a “trama' arquitetada por Daniel Leite” (JP, 2/9/2008, p.3).

Em 3 de setembro de 2008, as matérias do JP são intituladas: “Decisão histórica da Justiça Eleitoral do Maranhão. TRE-MA confirma candidatura de João Castelo a prefeito de SL: 5 a $0^{16}$. Juiz relator desmonta parecer do procurador eleitoral" e "A vitória de Castelo e a verdade real". Sobre a primeira, repercutiu a passagem em que o relator Roberto Veloso afirma que '... é de se exigir da Justiça Eleitoral que registre seus atos', lamentando que 'a Justiça está entregue aos servidores, não aos juízes" (JP, 3/9/2008, p. 3). Sobre a segunda, ressalta-se a ênfase de que: "O TRE demonstrou ser digno probo e, principalmente, capaz de justiça quando injustiças querem castigar o conjunto da população. Castelo é candidato contra as vontades de Sarney, Tadeu Palácio, Raimundo Cutrim e Clodomir Paz. É candidato porque assim o povo quer (...)" (JP, 3/9/2008, p 2).

O EM divulgou o posicionamento da presidente do TRE reafirmando que o órgão não errou, ratificando os procedimentos adotados e defendendo os servidores. O que gerou uma nota de solidariedade ao juiz federal assinada pelas Associação dos Juízes Federais do Brasil e Associação dos Juízes Federais da $1^{\text {a }}$ Região.

Apesar de persistir publicizando iniciativas de contestação à candidatura de João Castelo e apontando novas estratégias possivelmente mais eficazes para os demais candidatos no sentido de vencê-lo no segundo turno, o EM passa a centrar suas matérias no sentido de divulgar atos de campanha e projetos de governo do candidato Gastão Vieira (PMDB), em primeiro plano, e dos demais. No dia 12 de outubro, os jornais divulgaram a decisão do TSE de assegurar a participação de Castelo no segundo turno (juntamente com Flávio Dino, com o qual estaria "tecnicamente empatado"), diante o pedido de cassação encaminhado pelo vice-procurador geral eleitoral. Segundo notícia do EM, a decisão favorável foi tomada em uma sessão do Tribunal Superior Eleitoral, na qual somente os advogados de Castelo participaram (EM, 12/10/2008, p. 2). João Castelo Ribeiro Gonçalves venceu as eleições municipais na capital do Maranhão.

O caso em pauta revela novas alianças e oposições. Dessa vez, por meio dos periódicos, as ações de juízes, promotores e advogados, até mesmo funcionários da justiça, passam a ser objeto de avaliações e "juízos" ao sabor das rivalidades e lealdades políticas, assim como a serviço de forças políticas. Do mesmo modo, políticos e jornalistas sincronizam argumentos e exploram as ambiguidades da esfera jurídica em termos de valores, concepções de justiça, práticas e decisões e dos atores que nela se movimentam. Com efeito, assumem a posição de intérpretes do "estado democrático de direito",

\footnotetext{
${ }^{16} \mathrm{~A}$ mesma forma de apresentar o resultado da decisão TRE, associando os votos dados pelos juízes a um placar esportivo e transformando o embate jurídico numa vitória de um jogo aos moldes de uma partida futebolística, foi ativada com destaque no Programa de TV do chamado Horário Eleitoral Gratuito.
} 
GRILL, I. G.; REIS, E. T. Disputas faccionais, batalhas jurídicas e construções...

oscilando entre sua dimensão da "legalidade" e da "soberania popular" e mesclando repertórios discursivos ou artefatos que conferem sentido a essa dupla face da legitimação do chamado "regime democrático".

\section{Os Advogados e as Campanhas Políticas}

Pelo que foi exposto até aqui, fica patente a centralidade dos advogados e das "batalhas jurídicas" nas campanhas eleitorais. O conjunto de informações reunido na pesquisa mais ampla sobre advogados que faziam parte das equipes dos candidatos permitiu identificar algumas regularidades. Observa-se como, para a afirmação desses profissionais do direito eleitoral no espaço político, aliam-se competências, saberes e redes de relações pessoais. Recursos diretamente associados às origens familiares e ao pertencimento a "famílias" estabelecidas tanto social quanto politicamente. Seus usos, por sua vez, estão fortemente condicionados pelos códigos que prevalecem nas lutas faccionais caracterizadas como "acirradas", o que denota o enfrentamento pessoal e calcado no elemento da honra e reputação moral.

O objetivo perseguido nesta seção é cotejar diferentes itinerários de coordenadores jurídicos de equipes de campanhas, seus perfis, as características dos municípios nos quais atuam e como os escritórios, assim como os profissionais, estão interligados por redes cujas conexões se fundam em elos pessoais e na divisão do trabalho jurídico de atendimento a políticos. Para tanto, a comparação recai sobre o principal advogado da campanha de João Castelo (destacado na seção anterior) em contraste com dois advogados que trabalharam em disputas no interior do estado no pleito de 2008. 0 material coletado (entrevistas, informações biográficas e matérias veiculadas em jornais locais) abarca, então, as eleições de 2008 em São Luís, Caxias e Pinheiro - municípios que ocupam, respectivamente, o primeiro, o terceiro e nono lugar em tamanho de contingentes eleitorais no estado do Maranhão. O foco está centrado nos percursos escolares, profissionais e políticos, o lugar que os agentes ocupam nos empreendimentos políticos e a relevância dos seus saberes e competências nesse universo.

Como foi dito, em São Luís, a eleição municipal de 2008 foi ganha por João Castelo Ribeiro Gonçalves do PSDB. Com uma campanha marcada por alto grau de divisão de papéis (entre "políticos profissionais" pertencentes a "famílias de políticos" com "tradição" no estado e profissionais/especialistas em áreas "centrais" para uma campanha política), Castelo contou na "equipe", como um dos coordenadores de campanha, com o advogado José Antônio Almeida, conhecido regionalmente por sua destacada biografia no âmbito do direito e da política. Nascido em 1954, na capital do Maranhão, Almeida é descendente de uma "família tradicional" do estado e possui vários parentes com atuação política.

Formado pela Universidade Federal do Maranhão em 1977, atuou profissionalmente como: assessor de desembargador (1976-1977); diretor da Secretaria da Corregedoria-Geral de Justiça (1979); advogado da Amazônia Mineração S.A. (1979-1980), da Cia. Vale do Rio Doce (1980-1981) e da Florestas Rio Doce S.A. (1982); professor da UFMA (desde 1986); juiz do Tribunal Regional Eleitoral do Maranhão (1983-1987); procurador (1986-1992) e procurador-geral Adjunto (1987-1988) na 
OPINIÃO PÚBLICA, Campinas, vol. 18, n², novembro, 2012, p. $490-512$

Procuradoria-Geral do Estado do Maranhão; procurador na Procuradoria da Fazenda Nacional, São Luís (1993-1995).

Publicou várias obras relacionadas ao espaço jurídico, com destaque para a temática relacionada ao direito eleitoral. Especialista Docente em Direito Processual Civil pela UNI-DF, foi, ainda, professor da Escola Superior do Ministério Público do Estado do Maranhão e da Escola de Magistratura do Estado do Maranhão, assim como do curso de Pós-Graduação da Faculdade Cândido Mendes do Maranhão. Atualmente, cursa o doutorado em Direito na Universidade do Museo Social Argentino.

Primeiro-Secretário, Seccional (1985) e Presidente da OAB. MA (1989-1994), José Antonio Almeida foi indicado pela entidade, em 2007, para compor a lista sêxtupla dos advogados candidatos à vaga de desembargador pelo quinto constitucional, da qual os desembargadores do Pleno definiram três nomes encaminhados ao governador para a escolha do novo desembargador do Tribunal de Justiça.

Em 1998, concorreu a deputado federal pelo PSB (partido ao qual é filiado desde 1994), ocupando o cargo no período 1999-2002 e sendo líder e vice-líder da sua bancada no mandato. Foi candidato a prefeito de São Luís em 2000, à vice-presidência da República, em 2002, e a deputado federal em 2006. Foi membro da executiva estadual e nacional do PSB e atualmente é o presidente desse partido no Maranhão.

É considerado um dos principais especialistas em Direito Eleitoral do Maranhão (condição certificada pela atividade docente e pela produção bibliográfica), atendendo, ao longo dos últimos anos, dezenas de prefeitos espalhados pelo estado (que o procuram diretamente ou mediados por seus advogados locais). É apresentado nas matérias jornalísticas como "ex-deputado" e "dono de um escritório especializado em Direito Eleitoral". Em 2006, estampou na fachada de seu escritório o slogan de sua campanha a deputado federal "O Seu advogado em Brasília".

Como tal explicou, no Jornal Pequeno de 27 de julho de 2008, em matéria intitulada: "Enxurrada de impugnações marca início da campanha no Maranhão", já no início da campanha, a centralidade dos "embates jurídicos".

"O que está acontecendo é que a campanha eleitoral está evoluindo sob uma fiscalização mais intensa do Ministério Público. (...). Como houve a mudança de orientação no TSE, oS recursos do Ministério Público Eleitoral acabaram tendo êxito, e os impugnados tiveram de retirar suas candidaturas. (...). Por conta desse precedente, os promotores agora impugnaram praticamente todos os candidatos que tinham prestações de contas rejeitadas, sem analisar se as Câmaras Municipais aprovaram ou não; ou se a Justiça concedeu ou não medida liminar". (...). Além disso, (...) ocorre em muitos municípios uma disputa interna muito mais acirrada em diversos partidos. Desde o início da atual campanha, o escritório do advogado (...) ficou abarrotado de ações de defesa contra a enxurrada de impugnações" (JP, 27/07/2008, p. 3).

Percebe-se a interligação entre as modificações da atuação do Ministério Público e o acirramento das disputas eleitorais. Logo, as mudanças revelam as interdependências entre as atribuições (delegadas, assumidas ou reivindicadas) por membros do judiciário e as novas correlações 
GRILL, I. G.; REIS, E. T. Disputas faccionais, batalhas jurídicas e construções...

de forças entre lideranças políticas e seus seguidores em distintos níveis. Como consequência, os escritórios de advocacia dos especialistas nessa área do direito ficam "abarrotados de ações". Os advogados acionam, para sua afirmação simultaneamente profissional e política, as relações construídas ao longo das suas biografias no âmbito das esferas da família, dos partidos, do judiciário e da representação categorial.

Em outro município maranhense, Caxias, o candidato vitorioso nas eleições municipais de 2008 foi Humberto Coutinho (PDT), que se reelegeu prefeito. Os coordenadores da sua campanha dividiram-se em dois polos: um adjetivado de "mais técnico", constituído de profissionais do marketing político, especialistas em finanças e em direito eleitoral; e outro "mais familiar", que reunia seus parentes e aliados mais próximos ${ }^{17}$.

O coordenador do núcleo jurídico da campanha formou-se em Direito pela Universidade Federal do Maranhão e possui especialização em Direito Eleitoral pela Escola Superior de Advocacia da OAB, concluída em 2003. Nasceu em Brasília (DF) e é filho de comerciantes tidos como uma "família tradicional" de Caxias. Conta entre seus ascendentes com um ex-prefeito, um ex-presidente da Aliança Renovadora Nacional (Arena) e um ex-vereador no mesmo município.

Em 2004, trabalhou na assessoria jurídica da primeira candidatura exitosa de Humberto Coutinho, convidado pelo então coordenador jurídico e atual Procurador do Município e influenciado pelas relações de amizade que já tinha com os filhos do candidato desde a infância. Após dois anos de exercício de assessoria na Procuradoria-Geral do Município, voltou a trabalhar em campanhas políticas. Desta vez, na assessoria jurídica dos candidatos a deputado estadual, deputado federal e governador apoiados por Humberto Coutinho. Depois disso, retornou ao seu cargo na administração municipal, desligando-se novamente, em 2008, para atuar na campanha pela reeleição de Coutinho. Na ocasião, tinha somente 32 anos.

Nesse empreendimento, contou também com o suporte de um importante escritório de advocacia especializado em Direito Eleitoral, situado em São Luís. Os dois sócios desse escritório são descendentes de "famílias de políticos" (um deles é sobrinho de um ex-prefeito, ex-presidente da Federação dos Municípios do Maranhão e importante liderança do interior do estado e de um desembargador; o outro é primo de deputado estadual e ex-presidente da Assembleia Legislativa, com o qual trabalhou por um tempo, e de um deputado federal), militaram no movimento estudantil secundarista e universitário na UFMA, bem como em "grupos de esquerda".

Sobre a atuação da assessoria jurídica na campanha, descreve um membro da coordenação jurídica:

\footnotetext{
"Caxias é uma cidade em que o processo eleitoral é extremamente acirrado. Desde que houve essa polarização, em 2004, Dr. Humberto/Márcia, em que ele conseguiu lograr êxito, grande parte desse êxito à época, felizmente, foi creditado à atuação da assessoria jurídica na campanha(...). (...) é um estilo beligerante muito ataque e acusações, e acusações sérias, graves (...). A campanha política hoje é permeada de intensa atividade
}

\footnotetext{
17 Os dados utilizados foram coligidos a partir de Lima (2009), que fez trabalho de campo em 2008 na cidade de Caxias e defendeu uma monografia de conclusão do curso de Ciências Sociais na UFMA no ano seguinte.
} 
OPINIÃO PÚBLICA, Campinas, vol. 18, n², novembro, 2012, p. $490-512$

judicial (com audiências, acusações, defesas). Ou seja, termina que é uma atividade que é paralela à campanha eleitoral e termina às vezes sendo até mais intensa. Esse ano mesmo tem sido uma campanha (...) aparentemente tranquila no campo político, tanto que existe comentários assim: "Ah! Essa campanha de 2008 tá parada, tá muito tranquila, ninguém faz confusão nenhuma”, eu falo assim: ‘É por que eles não tão na minha pele, né?'. Pra ter uma ideia: em 2004, a campanha toda eu dei entrada em cerca de 150 ações... Isso, o último controle que eu fiz há uns 10 dias atrás, cerca de pouco mais de dois meses de campanha, há 10 dias atrás, eu já entrei com mais de 300 ações. Então, eu estimo que até o final da campanha eu fique com um saldo de cerca de 500 ações" (Entrevista com membro da equipe de campanha de Humberto Coutinho).

Nota-se, a partir desse núcleo de agentes vinculados à candidatura, mais uma vez a mescla de critérios políticos, profissionais, familiares, de amizade, enfim, de redes de relações mais ou menos pessoalizadas, na constituição de protagonistas de um "jogo de bastidores". As lutas entre facções passam a ocorrer igualmente no âmbito judicial, motivadas por rivalidades políticas e por códigos de honra, atualizadas na nova linguagem e regramento, e com destaque para os advogados que se profissionalizam via complexificação e racionalização das campanhas, bem como a retribuição dos serviços prestados também em forma de cargos públicos.

Por fim, no município de Pinheiro, o então vice-prefeito José Arlindo Silva Sousa (DEM) elegeuse prefeito em 2008. Como nas disputas e candidaturas anteriormente tratadas, foi possível identificar uma tendência de profissionalização do espaço político (nas áreas de finanças, marketing e direito eleitoral), concomitantemente à importância das relações pessoais ${ }^{18}$.

O coordenador jurídico da equipe de campanha do candidato vitorioso nasceu em Imperatriz e possuía 26 anos no ano da eleição. Ele é formado em direito por uma faculdade particular da capital, a Faculdade São Luís. Seu pai foi secretário municipal de administração em Imperatriz (em duas gestões) e em Pinheiro (2001-2004). Nessa administração, José Arlindo era o vice-prefeito. Seu pai aproximou-se das principais lideranças políticas do município por intermédio de um diretor da Companhia Energética do Maranhão, ex-deputado estadual e oriundo de Pinheiro.

O advogado aqui analisado foi estagiário na Procuradoria Jurídica do município de Imperatriz e sua iniciação em campanhas políticas teria se dado em 2004, quando estagiou no setor jurídico da equipe comandada pelo atual deputado estadual Vitor Mendes (PV) ${ }^{19}$. Sendo este último filho do então candidato à reeleição (prefeito de Pinheiro entre 2001 e 2008, e atual secretário estadual do governo de Roseana Sarney) e neto de ex-prefeito. Trata-se de uma "família de políticos" cujos membros são marcados pela lealdade à liderança dos políticos da "família Sarney"20.Trabalhou, também, atendendo outras prefeituras, em destacado escritório especializado em direito eleitoral de São Luís, comandado por um advogado que costuma ser associado no meio político, jurídico e jornalístico como também

\footnotetext{
${ }^{18}$ Os dados utilizados nesta parte do artigo fazem parte de um trabalho mais amplo que originou uma Dissertação de Mestrado defendida no Programa de Pós-Graduação em Ciências Sociais da UFMA (ARAgÃo, 2010).

${ }^{19}$ Por conta dessa relação, chegou a se filiar ao Partido Verde (PV).

${ }^{20}$ Pinheiro é o município de origem do ex-governador, ex-presidente da República e atual senador José Sarney, e uma das principais "bases eleitorais" do seu filho, Sarney Filho (deputado federal).
} 
GRILL, I. G.; REIS, E. T. Disputas faccionais, batalhas jurídicas e construções...

ligado à "família Sarney", sendo, inclusive, o atual Procurador-Geral do Estado no governo de Roseana Sarney.

Em entrevista, destacou, além dos aspectos já salientados nos casos anteriores, a relevância da "comunicação" entre as coordenadorias de marketing e jurídica (elementos da mesma forma aludidos por outros entrevistados). Grifando: "Tudo que ela [coordenadora de marketing] quer colocar no programa eleitoral passa pelo meu crivo e aí eu digo 'pode isso, não pode aquilo', para evitar que as propagandas sejam retiradas do ar". Além disso, ressalta que, até aquele momento (de realização da entrevista, 13/09/2008), nenhum programa da coligação havia sido "retirado do ar" ou "proibido de ser veiculado", assim como já havia enviado 15 representações à Justiça Eleitoral para suspensão de programas eleitorais de TV dos adversários, sendo "apenas três dos pedidos indeferidos" (entrevista com coordenador jurídico da campanha de José Arlindo).

Nota-se a vinculação entre profissionais e escritórios da capital e do interior em uma espécie de hierarquização dos agentes segundo a proximidade com o centro e a relevância social, política e demográfica dos municípios. Isso se traduz na diferenciação do status político e profissional dos coordenadores jurídicos tratados nesta seção e atuantes em municípios discrepantes, que apresentam uma nítida distância em termos de prestígio e notoriedade.

\section{Considerações Finais}

A análise empreendida neste artigo partiu do referencial produzido pela Sociologia Política francesa para refletir sobre as intersecções entre o mundo jurídico, político e midiático, bem como para compreender as interdependências entre esses domínios da vida social em universos marcados pelas disputas faccionais, pelas relações personalizadas e por redes de relações que perpassam os diversos planos de ação dos agentes. Foi possível, assim, evidenciar as alianças, osmoses, rivalidades, aproximações e distanciamentos em uma configuração cujas fronteiras são marcadas pela porosidade extrema ou pela indiferenciação das esferas. Ademais, os trânsitos, fluxos e trocas entre os espaços de atuação são regidos por códigos de lealdades, reciprocidade e hostilidade entre protagonistas ligados pelo pertencimento ao mesmo círculo de interconhecimento e interreconhecimento.

Desse modo, o equilíbrio de poder entre personagens; os papéis atribuídos aos variados profissionais (políticos, juízes, promotores, advogados e jornalistas) submetidos a lógicas de concorrência e de cooperação e as influências recíprocas que exercem uns sobre os outros e que são legitimadas por critérios de justificação seletivos e móveis desvelaram um cenário bem mais complexo e multifacetado do que aquele concebido pela bibliografia consultada. Cumpre, assim, investir em análises que explorem, simultaneamente, os múltiplos setores sociais envolvidos e a multiposicionamento dos agentes; os referenciais amalgamados e justapostos que os orientam; os padrões de excelência profissional importados e as reputações advindas de espaços estruturados a partir do monopólio desfrutado por fechados círculos de famílias às fontes de recursos; sem deixar de mencionar os diferentes níveis (do local ao nacional) de funcionamento das arenas de lutas políticas, jurídicas, midiáticas, a hierarquização entre elas e como constituem diferentes regras, relações e gramáticas próprias, mas mutuamente interligadas. 
OPINIÃO PÚBLICA, Campinas, vol. 18, nº 2, novembro, 2012, p. $490-512$

\section{Referências Bibliográficas}

ARAgão, E. R. O. Raposas, Herdeiros e Outsiders: especialização política e dinâmica eleitoral em Pinheiro - MA. São Luís. Dissertação (Mestrado) - Universidade Federal do Maranhão, Centro de Ciências Humanas, 2010.

BARREIRA, I. "A política de perto: recortes etnográficos de campanhas eleitorais". Novos Estudos - CEBRAP, vol. 74, 2006.

BARROS FILHO, J. A tradição engajada: origens, redes e recursos eleitorais no percurso de Flávio Dino. In : GRILL, I. G.; ReIS, E. T.; BARRos FIlho, J. Elites, Profissionais e Lideranças Políticas: pesquisas recentes. São Luís: EDUFMA, 2008.

BoIssevaIn, J. Factions, parties and politics in a maltese village. In: SchmidT, S.W. et al. (Eds.). Friends, Followers and Factions. A Reader in political clientelism. Berkeley: University of California Press, 1977.

Bonelli, M. da G. Profissionalismo e política no mundo do direito. São Carlos, Sumaré: Edufscar/FAPESP, 2002.

Bourdieu, P. A representação política. Elementos para uma teoria do campo político. In: BouRdiEU, P. O Poder simbólico. Lisboa: Difel, 1989.

Braud, P. Le Jardim des Délices Démocratiques. Paris: Presses de la Fondation Nationale des Sciences Sociales, 1991.

Champagne, P. Formar a opinião: o novo jogo político. Petrópolis: Vozes, 1998.

Collovald, A. “De la défense des pauvres nécessiteux à l'humanitaire expert. Reconversion et métamorphoses d'une cause politique". Politix, n 56, p. 135 - 161, 2001

Coradini, O. L. A Extração Social dos Candidatos: As Eleições de 1990 e de 1994 no Rio Grande do Sul. Rio de Janeiro: NAU, 1999

2001.

. Em nome de quem? Recursos sociais no recrutamento de elites políticas. Rio de Janeiro: Relumé-Dumará,

Dezalay, Y.; GARTH, B. La Mondialisation des Guerres de Palais. La restructuration du pouvoir d’État en Amerique Latine, entre notables du droit et "Chicago Boys". Paris: Éditions du Seuil, 2002.

Dogan, M. Les Professions Propices à la Carrière Politique. Osmoses, Filières et Viviers. In: OfFERLE, M. (org.). La profession politique. Paris: Belin, 1999.

DuLONG, D. “Quand l'economie devient politique. Laconversion de la compétence economique en compétence politique sous la V Republique". Politix, n³5, 1996.

EngelmanN, F. "Internacionalização e ativismo judicial: as causas coletivas”. Lua Nova. Revista de Cultura e Política, vol.69, 2006

GAITI, B. La Science dans la mêlée : usages croisés des discurs savants et militants". In : HAMmAN, P.; MEON, J.-M. \& VERRIER, B. Dicours savants, discours militants: mélange des genres. Paris: l'Harmattan, 2002.

GaITI, B.; ISRAEL, L. "Sur l'engajement du droit dans la construction des causes”. Politix, n 62, 2003.

GARLAND, C. D. “Formulation et réformulation d'une cause, le cas des droit de l'homme au Chili de la dictature à la politique de reconciliation nacionale". Politix, n 62, 2003.

GARRAUD, P. La politique à l'épreuve du jugement judiciaire. La pénalisation croissante du politique comme 'effet induit' du processus d'autonomisation de l'institution judiciaire. In : BRIQUET, J.L. ; GARRAUD, P. (orgs.). Juger la politique: entreprises et entrepreneurs de la politique. Paris: Présses Universitaires Rennes, 2001.

2003.

. Tranformations des pratiques politiques et rôles de juges. In: LAGROYE, J. (org). La politisation. Paris: Belin,

GAXIE, D. Une construction médiatique du spectacle politique? Réalité et limites de la contribution des médias au développement des perceptions négatives du politique. In: LAGROYE, J. (orgs.). La politisation. Paris: Belin, 2003.

Grezes-RuefF, F. La Culture des Députés Français (1910-1958): Essai de typologie. Toulouse: Presses Universitaires du Mirail, 1994. 
GRILL, I. G.; REIS, E. T. Disputas faccionais, batalhas jurídicas e construções...

GRILL, I. G.; CostA, D. dos S. D.; ARAGÃo, E. R. O.; LIMA, J. G. do N. "Bases sociais, alianças e mediação na seleção de elites locais no Maranhão (2008)". In: 33 Encontro Anual da Anpocs, 2009.

GRILL, I.G. “'Família', Direito e Política no Rio Grande do Sul: os usos do parentesco e dos títulos escolares no exercício do métier". Tomo, n 10, 2007.

ISRAEL, L. "Usages militants lawyering". Droit et Societé, n 49, 2001.

LAGROYE, J. "Le Leadership en question. Configurations et formes de domination". In: SMITH, A.; SorBETS, C. (orgs.). Leadership Politique et le Territoire. Paris: Présses Universitaires Rennes, 2003.

LANDÉ, C. "Groups politics and dyadic politics: notes for a theory". In: SCHMIDT, S.W. et al (Eds.). Friends, Followers and Factions. A Reader in political clientelism. Berkeley: University of California Press, 1977.

LIMA, J. G. Do N. Bases Sociais, Faç̧ões e Mediação: o processo de seleção de "elites locais" e a dinâmica de concorrência eleitoral em um município maranhense. Monografia de Conclusão do Bacharelado em Ciências Sociais Universidade Federal do Maranhão, Centro de Ciências Humanas, 2009.

MARQUetTI, D. "Les révélations du jornalisme d'investigation". Actes de la Recherche em Sciences Sociales, n 131-132, 2000 .

"Le journalisme d'investigation: gênese et consecration d'une spécialité journalistique. In : BRIQUET, J.L.; GarRaud, P. Juger la politique : entreprises et entrepreneurs de la politique. Paris: Présses Universitaires Rennes, 2001.

Matontı, F. ; Poupeau, F. "O capital militante. Uma tentativa de definição". Plural, n 13, 2006.

MAYER, A. "The Significance of Quase-group in the Study of Complex Societies". In: SCHMIDT, S.W. et al (Eds.). Friends, Followers and Factions. A Reader in political clientelism. Berkeley: University of California Press, 1977.

MUSELA, L. "La classe politique en jugement. Tangentopoli et la critique de la politique en Italie". In : BRIQUET, J.L. ; GARRAUD, P. (orgs.). Juger la politique : entreprises et entrepreneurs de la politique. Paris: Présses Universitaires Rennes, 2001.

NeVeu, E. Sociologia do Jornalismo. São Paulo : Edições Loyola, 2006.

Palmeira, M. Eleição Municipal, política e cidadania. PalmeIRa, M.; Barreira, C. (orgs.). Política no Brasil: Visões de antropólogos. Rio de Janeiro: Relume-Dumará, 2006.

PeRISSINOTTO, R. M. et al. "Origem social dos parlamentares paranaenses (1995-2006): alguns achados e algumas questões de pesquisa". Sociologias, vol. 22, 2009.

Petrarca, F. R. "Igualdade Racial, Ativismo Jurídico e Defesas de Causas Coleitvas no Rio Grande do Sul". In: 14 Encontro de Ciências Sociais do Norte e Nordeste, 2009. Recife. Anais do $14^{\circ}$ Encontro de Ciências Sociais do Norte e Nordeste. Recife : FUNDAJ, 2009.

Rodrigues, L. M. Partidos, Ideologia e Composição Social. São Paulo: Edusp, 2002.

Roussel, V. "Les magistrats dnas les scandales politiques en France. Logiques d'action et jeux judiciaires locaux. In: BRIQUet, J.L. ; GaRRAUD, P. (orgs.). Juger la politique : entreprises et entrepreneurs de la politique. Paris: Présses Universitaires Rennes. 2001.

"Les magistrats français, des cause lawyers malgré eux". Politix, n 62, 2003.

Santamaria, A.; Vecchioli, V. (Orgs.). Derechos Humanos en América Latina: Mundialización y circulación internacional del conociemento experto jurídico. Bogotá/Colombia: Ed Universidad del Rosario/ Centro de Estúdios Políticos Internationales, 2008.

SAntos, A. M.; SeRnA, M. "Por que Carreiras Políticas na Esquerda e na Direita não são iguais? Recrutamento Legislativo em Brasil, Chile e Uruguai". Revista Brasileira de Ciências Sociais. São Paulo, vol 22, n 64, p. 94-113, 2007.

SAWICKI, F. Le Leadership politique. In: SMITH. A. e SORBERTS, C. (orgs.). Le Leadership Politique et le Territoire. Rennes: Présses Uniniversitaires Rennes, 2003.

SIMEANT, J. Friches, hybrides et contrebandes: sur la circulation et la puissance militantes des discours savants. In: HAMmAn, P.; MÉON, J.M. \& VeRRIER, B. (orgs.). Discours savants, discours militants: mélange des genres. Paris: L'Hartmattan, 2002. 
OPINIÃO PÚBLICA, Campinas, vol. 18, n², novembro, 2012, p. $490-512$

TAVARES dos ReIS, E.; GriLl, I. G. "Letrados e Votados: lógicas cruzadas do engajamento político no Brasil”. Tomo. n 13 , 2008

TURNER, V. O processo ritual. Petropólis: Vozes, 1974.

VERRIER, B. Expert, idéologue, militant: la production d'une ressouce socialiste (1964-1969). In: HAMmAN, P.; MEON, J.-M. \& VERRIER, B. (orgs.). Dicours savants, discours militants: mélange des genres. Paris: L'Harmattan, 2002.

Les Transformations d'une marque politique. Du CERES au MDC. In: COHEN, A. ; LACROIX, B. ; RIUTORT, P. (orgs.). Les Formes de l'activité politique. Paris: PUF, 2006

ViannA, L.W. et al. Corpo e Alma da Magistratura Brasileira. Rio de Janeiro: Revan, 1997.

Weber, M. Ciência e Política: duas vocações. São Paulo: Cultrix, 1993.

Willemez, L. “La 'Republique des Avocats'”. In : Offerle, M. La Profession politique. Paris: Belin, 1999.

"Engagement professionnel et fidélités militantes. Les avocats travaillistes dans la défense judiciaire des salariés". Politix, n 62, 2003.

Periódicos Citados:

Jornal Pequeno

Jornal Estado do Maranhão

Igor Gastal Grill - igorgrill@terra.com.br

Eliana Tavares dos Reis - eliana1reis@terra.com.br

Submetido à publicação em julho de 2010.

Versão final aprovada em junho de 2011. 